\title{
PERLINDUNGAN HUKUM TERHADAP PURA TAMAN MAYURA CAKRANEGARA SEBAGAI KAWASAN CAGAR BUDAYA DI KOTA MATARAM
}

\author{
Anak Agung Ketut Wardiani, I Nyoman Suarna, I Nyoman Sumantri \\ IAHN Gde Pudja Mataram
}

\begin{abstract}
Abstrak
Penelitian ini bertujuan untuk Mengetahui bentuk perlindungan hukum Situs Cagar Budaya Pura Taman Mayura. Dan Mengetahui faktor yang menjadi kendala perlindungan hukum terhadap Cagar Budaya Pura Taman Mayura. Penelitian ini menggunakan metode penelitiaan hukum yaitu penelitiaan bersifat normatif empiris. Penelitiaan normatif empiris fokusnya adalah penelitiaan tentang asas-asas hukum, sistematika hukum singkronisasi hukum, sejarah hukum dan perbandingan hukum dan juga bagaimana pelaksanaan hukum itu berlaku Perlindungan hukum terhadap cagar budaya taman mayura dilakukan atas dasar aturan yang dalam peraturan perundang undangan. kendala kendala yang dihadapi dalam pengeloaan cagar budaya pura taman mayura terdapat dua kendala yakni dari pemerintah daerah seperti belum adanya peraturan daerah yang mengatur tentang cagar budaya dan yang kedua dari pengelolaan sendiri yang sering tumpeng tindih antara yayasan dan pemerintah terkait dengan tanggungjawab apabila terjadi kerusakan cagar budya.
\end{abstract}

Kata Kunci : pura mayura, perlindungan hukum, cagar budaya

\section{A. Latar Belakang}

Kebudayaan adalah hasil karya dan bukti eksistensi manusia pada zaman dahulu dalam rangka untuk mempertahankan hidupnya. Kebudayaan manusia terbentuk karena aktivitas yang dilakukan secara terpola dan menjadi kebiasaan yang dilestarikan oleh pengikutnya karena dipandang sebagai metode terbaik untuk menunjang kelangsungan hidup. Umumnya kebudayaan di suatu tempat atau wilayah berbeda dengan wilayah yang lain. Hal ini dikarenakan proses adaptasi manusia yang berbeda tergantung dengan kondisi alam tinggalnya. 
Menurut Kamus Besar Bahasa Indonesia kebudayaan diartikan sebagai sebuah hasil karya, pola pikir, adat istiadat yang telah lama dijalankan dan sukar diubah. Sedangkan menurut Koentjoroningrat (1985: 180) kebudayaan adalah seluruh sistem gagasan, tindakan dan hasil karya manusia dalam rangka kehidupan masyarakat yang dijadikan milik dari manusia dengan belajar. Sehingga kebudayaan merupakan sebuah hal penting yang harus dilindungi dan dilestarikan keberadaannya agar dapat bermanfaat untuk generasi yang akan datang. Kebudayaan dapat berbentuk kebiasaan, adat istiadat, istilah, bahasa, benda ataupun bangunan, kesenian dan lain sebagainya. Menurut JJ. Hoeningman (dalam Herimanto dan Winarno, 25: 2009) membagi wujud kebudayaan menjadi tiga yaitu antara lain:

(1) Gagasan (wujud ideal) Wujud ideal kebudayaan adalah kebudayaan yang berbentuk kumpulan ide, gagasan, nilai, norma, peraturan, dan sebagainya yangsifatnya abstrak; tidak dapat diraba atau disentuh. Wujud kebudayaan ini terletak dalam kepala atau di alam pikiran warga masyarakat. Jika masyarakat tersebut menyatakan gagasan mereka itu dalam bentuk tulisan, maka lokasi dari kebudayaan ideal itu berada dalam karangan dan buku-buku hasil karya para penulis warga masyarakat tersebut.

(2) Aktivitas (tindakan) Aktivitas adalah wujud kebudayaan sebagai suatu tindakan berpoladari manusia dalam masyarakat itu. Wujud ini sering pula disebutdengan sistem sosial. Sistem sosial ini terdiri dari aktivitas-aktivitasmanusia yang saling berinteraksi, mengadakan kontak, serta bergaul dengan manusia lainnya menurut pola-pola tertentu yang berdasarkan adat tata kelakuan. Sifatnya konkret, terjadi dalam kehidupan sehari-hari, dan dapat diamati dan didokumentasikan.

(3) Artefak (karya) Artefak adalah wujud kebudayaan fisik yang berupa hasil dariaktivitas, perbuatan, dan karya semua manusia dalam masyarakat berupa benda-benda atau hal-hal yang dapat diraba, dilihat, dan didokumentasikan. Sifatnya paling konkret di antara ketiga wujud kebudayaan. 
Ketiga wujud kebudayaan tersebut adalah bagian dari kekayaan bangsa yang harus dilindungi, dilestarikan, dan dimanfaatkan untuk kepentingan nasional. Oleh karena itu, dalam rangka melindungi dan melestarikan kebudayaan dibutuhkan Sikap dan komitmen yang serius dari pemerintah serta dukungan dari seluruh elemen masyarakat supaya dapat terwujud kebudayaan yang lestari sehingga dapat digunakan sebesar-besarnya untuk kemakmuran rakyat. Salah satu peninggalan kebudayaan yang patut mendapatkan perhatian ekstra adalah peninggalan kebudayaan yang bersifat konkret yang disebut dengancagar budaya. Cagar budaya merupakan hasil kebudayaan berupa artefak atau hasil karya.

Keberadaan cagar budaya harus benar-benar dirawat dan dijaga karena sifatnya yang rapuh yang disebabkan oleh berbagai faktor baik faktor manusia maupun faktor alam, memiliki usia panjang, dan tidak bisa diperbaharui. Urgensi perlindungan cagar budaya dijelaskan di dalam Undang-Undang Nomor 11 Tahun 2010 tentang Cagar Budaya, bahwasanya cagar budaya merupakan kekayaan budaya bangsa sebagai wujud pemikiran dan perilaku kehidupan manusia yang penting bagi pemahaman dan pengembangan sejarah, ilmu pengetahuan, dan kebudayaan dalam kehidupan bermasyarakat, berbangsa, dan bernegara sehingga perlu dilestarikan dan dikelola secara tepat melalui upaya perlindungan, pengembangan, dan pemanfaatan dalam rangka memajukan kebudayaan nasional untuk kemakmuran rakyat. Kemudian di dalam Undang-Undang Nomor 11 Tahun 2010 pengertian cagar budaya adalah warisan budaya yang bersifat kebendaan berupa benda cagar budaya, bangunan cagar budaya, struktur cagar budaya, situs cagar budaya, dan kawasan cagar budaya di darat dan atau di air yang perlu dilestarikan keberadaannya karena memiliki nilai penting bagi sejarah, ilmu pengetahuan, pendidikan, agama, dan atau kebudayaan melalui proses penetapan. Cagar budaya merupakan bagian dari kebudayaan, oleh karena itu perlindungan cagar budaya juga mengacu pada undang-undang yang tertinggi yaitu UndangUndang Dasar 1945.

Menurut Pasal 32 ayat (1) Undang-Undang Dasar 1945 disebutkan bahwa "Negara memajukan kebudayaan nasional Indonesia di tengah peradaban dunia dengan menjamin kebebasan masyarakat dalam memelihara dan mengembangkan nilai-nilai budayanya." Hal tersebut menunjukkan bahwa perlindungan, pengembangan, dan 
pemanfaatan cagar budaya merupakan hal penting yang harus dilaksanakan demi kepentingan seluruh bangsa.

Negara juga memberikan jaminan kebebasan kepada masyarakat untuk ikut memelihara dan mengembangkan cagar budaya, sehingga nilai-nilai dari cagar budaya tersebut dapat masuk ke dalam kehidupan masyarakat. Selain itu, cagar budaya adalah kekayaan bangsa yang diwariskan oleh manusia pada zaman dahulu yang dapatbermanfaat untuk memupuk jati diri bangsa baik untuk generasi sekarang maupun generasi yang akan datang. Pelestarian cagar budaya di Indonesia telah berjalan sejak masa pendudukan kolonial Belanda. Didasari oleh beberapa hasil riset dan temuan dari peneliti dan arkeolog Belanda terhadap benda-benda purbakala, Pemerintah Belanda kemudian mendirikan suatu badan yang bersifat sementara pada tahun 1901 yang bernama Comissie In Nederlandsch - Indie Voor Oudheidkundig Onderzoek op Java en Madoera yang bertujuan untuk melakukan riset, pengawasan, dan perlindungan terhadap peninggalan purbakala di Indonesia pada saat itu.

Menurut website cagar budaya kemdikbud

Taman Mayura di bangun pada masa pemerintahan Raja I Gusti Wayan Taga (1741-1771 M), beliau berasal dari keturunan Kerajaan Singasari atau Karangasem Sasak Lombok, pada tahun 1839 Kerajaan Singasari dikalahkan oleh Kerajaan Mataram. Kemudian Raja Mataram yang bernama Anak Agung Ngurah Karangasem membangun puri yang diberi nama Puri Cakranegara di atas bekas Puri Kerajaan Singasari yang hancur termasuk memperbaharui Taman Mayura yang sebelumnya bernama Taman Kelepug (berarti mata air, dalam bahasa Bali) tahun 1866. Taman Mayura dibangun sebagai kelengkapan bangunan puri (istana) raja, yang terletak di sebelah barat kompleks taman ini (sekarang berdiri perusahaan tenun). Sebagai taman raja, di dalam kompleks Taman Mayura terdapat rumah tempat peristirahatan raja (letaknya sekarang berdiri Pura Padmasana). Taman ini dibangun dengan maksud sebagai halaman pura, pemeliharaan bunga-bunga, dan burung mayura (burung merak), dan sejak saat itu taman ini dikenal dengan nama Taman Mayura. (https://cagarbudaya.kemdikbud.go.id/public/objek/detailcb/PO2016060600002/tama n-mayura. Diunduh tanggal 15 april jam 09.00 wita)

Situs cagar budaya merupakan salah satu wujud artefak kebudayaan peninggalan zaman dahulu, sehingga keberadaannya wajib dilindungi oleh semua pihak 
baik pemerintah pusat, pemerintah daerah, maupun masyarakat. Segala bentuk aktivitas manusia yang cenderung merusak, mencemari, dan berpotensi menghilangkan nilainilai yang terkandung di dalam cagar budaya harus segera ditindak dengan tegas. Tindakan asusila yang marak dilakukan di lokasi Taman mayura serta keberadaan pertunjukan Band yang berada di dekat kawasan Pura Taman Mayura tidak hanya merupakan pelanggaran, melainkan juga mencemari nilai historis dan keagamaan situs cagar budaya Pura Taman Mayura. Taman mayura sendiri sudah ditetapkan menjadi situs cagar budaya dengan SK penentapan SK Menteri No PM.19/PW.007/MKP/2007.

Dengan demikian, penulis ingin menganalisis secara yuridis sosiologis bagaimana dasar hukum dalam perlindungan hukum terhadap pura taman mayura sebagai cagar budaya, mengetahui apa kendala yang dihadapi dalam memberikan perlindungan hukum terhadap pura taman mayura, sehingga Pura Taman Mayura dapat terjaga kelestariannya dan bermanfaat untuk kegiatan ilmiah, kegiatan keagamaan, dan sebagai objek pariwisata di Kota Mataram. Oleh sebab itu, penulis menyusun skripsi dengan judul Perlindungan Hukum Pura Taman Mayura Sebagai Cagar Budaya

\section{B. Rumusan Masalah}

Dari latar belakang dan pembatasan masalah di atas, maka perumusan masalah yang akan diteliti oleh penulis yaitu:

1. Bagaimanakah bentuk perlindungan hukum situs Cagar Budaya Pura Taman Mayura?

2. Apa saja kendala yang dihadapi dalam perlindungan hukum terhadap Situs Cagar Budaya Pura Taman Mayura?

\section{Metode Penelitian}

Berdasarkan apa yang menjadi permasalahan dalam penelitiaan ini, maka peneliti menggunakan metode penelitiaan hukum yaitu penelitiaan bersifat normatif empiris. Penelitiaan normatif empiris fokusnya adalah penelitiaan tentang asas-asas hukum, sistematika hukum singkronisasi hukum, sejarah hukum dan perbandingan hukum dan juga bagaimana pelaksanaan hukum itu berlaku. (Zainudin Ali, 2009 :24) 
(Depri Liber Sonata, 2014) metode penelitiaan hukum normatif dan empiris: karakteristik khas metode penelitiaan hukum. Dapat disimpulkan pembahasanya mengenai penelitiaan hukum normatif dari sifat dan ruang lingkup disiplin hukum, dimana disiplin diartikan sebagai suatu sistem ajaran tentang kenyataan, yang biasanya mencangkup disiplin analitis dan preskriptif jika hukum hanya dipandang sebgai norma hukum secara normatif. Penelitian normaatif memiliki kecendrungan dalam mencitrakan hukum subagai disiplin preskriptif dimana hanya melihat hukum dari sudut norma-normanya saja.

\section{Pembahasan}

\section{Perlindungan Hukum Situs Cagar Budaya Taman Mayura}

Konsep pelestarian cagar budaya dalam Undang-undang No. 5 Tahun 1992 tentang Benda Cagar Budaya tidak dirumuskan secara eksplisit namun cukup menggambarkan bahwa arti pelestarian cenderung mengacu kepada upayaupaya pelindungan yang bersifat statis, misalnya dengan membuat batasanbatasan secara relatif ketat pada akfitas pengembangan dan pemanfaatan yang dianggap berpotensi merusak cagar budaya. Oleh karena itu munculah kesan bahwa upaya-upaya pengembangan atau pemanfaatan dapat mengancam kelestarian jika tidak dikendalikan secara ketat. Pemahaman tentang konsep pelestarian yang dipertentangkan dengan pengembangan atau pemanfaatan sesungguhnyamasih terjadi hingga saat ini. Oleh karena itu dak mengherankan bila konsep pelestarian yang dirumuskan dalam undang-undang cagar budaya yang baru belum banyak dipahami oleh masyarakat luas. Dalam bagian ketentuan umum Undang-undang No. 11 tahun 2010 tentang Cagar Budaya dijelaskan bahwa yang dimaksud dengan pelestarian adalah upaya dinamis untuk mempertahankan keberadaan cagar budaya dan nilainya dengan cara melindungi, mengembangkan, dan memanfaatkannya.

Rumusan ini menegaskan bahwa pengembangan dan pemanfaatan juga merupakan bagian dari perlestarian. Paradigma baru ini sesungguhnya juga berlaku untuk warisan budaya tak benda (intangible cultural heritage) yang 
sebelumnya dikhawatirkan terancam bahaya karena dieksploitasi untuk kepentingan pariwisata atau terpinggirkan karena dampak globalisasi kebudayaan.

Perlindungan pada dasarnya merupakan upaya untuk mencegah (preventif) dan menanggulangi cagar budaya dari kerusakan, kehancuran dan kemusnahan dengan cara penyelamatan, pengamanan, zonasi, pemeliharaan, dan pemugaran. Dalam kaitannya dengan kawasan cagar budaya, zonasi merupakan ndakan perlindungan yang paling penting. Zonasi sebagai sarana untuk mengendalikan pemanfaatan ruang yang dilakukan_dak hanya terhadap kawasan tetapi juga terhadap situs. Selain zonasi, terdapat kegiatan-kegiatan lain yang biasanya ditujukan untuk melindungi benda, bangunan, dan struktur. Kegiatankegiatan tersebut mencakup penyelamatan, pengamanan, pemeliharaan, dan pemugaran.

Perlindungan hukum yang berkaitan dengan benda cagar budaya terdapat pada ketentuan dalam Pasal 95 ayat (1) Undang-Undang Republik Indonesia Nomor 11 Tahun 2010 tentang Cagar Budaya (Lembar Negara Republik Indonesia Nomor 130 Tahun 2010) bahwa: "Pemerintah dan atau Pemerintah Daerah mempunyai tugas melakukan Perlindungan, Pengembangan, dan Pemanfaatan Cagar Budaya.

Pelindungan adalah unsur terpenting dalam sistem pelestarian cagar budaya, unsur ini mempengaruhi unsur-unsur lain yang pada akhirnya diharapkan menghasilkan umpan balik (feedback) pada upaya pelindungan. Unsur ini langsung berhubungan langsung dengan fisik (tangible) cagar budaya yang menjadi bukti masa lalu. Pengaturan Undang-Undang No. 11 Tahun 2010 tentang Cagar Budaya menekankan cagar budaya yang bersifat kebendaan, dimana Cagar Budaya adalah warisan budaya bersifat kebendaan berupa Benda Cagar Budaya, Bangunan Cagar Budaya, Struktur Cagar Budaya, Situs Cagar Budaya, dan Kawasan Cagar Budaya di darat dan/atau di air yang perlu dilestarikan keberadaannya karena memiliki nilai penting bagi sejarah, ilmu pengetahuan, pendidikan, agama, dan/atau kebudayaan melalui proses penetapan.

Keberadaan cagar budaya pada era pasca lahirnya Undang-Undang Nomor11 Tahun 2010, memberikan kewenangan dan peran yang lebih besar 
kepada pemerintah daerah untuk melakukan perlindungan dan pelestarian terhadap cagar budaya. Salah satu tujuan di balik lahirnya undang-undang tersebut adalah upaya pelestarian, pengelolaan, dan pemanfaatan cagar budaya yang digunakan untukmenunjang kepentingan daerah demi tercapainya tujuan dan cita-cita nasional bangsa.

Dalam perlindungan hukum terhadap situs cagar budaya Taman Mayura diperlukan payung hukum sebagai landasan perlindungan hukum adapun landasan hukumnya yaitu:

1. Undang-Undang Dasar Republik Indonesia Tahun 1945 Pasal 32 ayat (1)

2. Undang-Undang No. 23 Tahun 2014 tentang Pemerintahan Daerah. Pasal 236

3. Undang-Undang No. 11 Tahun 2010 tentang Cagar Budaya. Pasal 95 dan Pasal 96

4. Peraturan Menteri Kebudayaan dan Pariwisata No. PM.57/PW.007/MKP/2010

5. Peraturan Menteri Pendidikan dan Kebudayaan Nomor 28 Tahun 2013 tentang Organisasi dan Tata Kerja Balai Pelestarian Cagar Budaya. Pasal 1 Sedangkan peraturan daerah untuk perlindungan cagar budaya yang ada di nusa tenggara barat belum ada sehingga menjadi masalah teknis kedepannya.

Dalam konteks pelestarian, upaya pengembangan didefiniskan sebagai peningkatan potensi nilai, informasi, dan promosi cagar budaya serta pemanfaatannya melalui penelitian, revitalisasi, dan adaptasi. Kegiatan pengembangan harus memperhatikan prinsip kemanfaatan, keamanan,keterawatan, keaslian, dan nilai-nilai yang melekat padanya. Adapun arahpengembangan adalah untuk memacu pengembangan ekonomi yang hasilnya untuk pemeliharaan cagar budaya dan kesejahteraan masyarakat.Penelitian dalam konteks pengembangan ini dilakukan untukmenghimpun informasi serta mengungkap, mendalami, dan menjelaskan nilai nilai budaya. Penelitian untuk pengembangan dapat dilakukan sebagai bagian yang berdiri sendiri, baik berupa penelitian dasar atau penelitian terapan. Penelitian juga dapat dilaksanakan dalam 
kerangka analisis mengenai dampak lingkungan. Adapun revitalisasi ditujukan untuk menumbuhkan kembali nilainilai penting cagar budaya dengan penyesuaian ruang baru yang tidak bertentangan dengan prinsip pelestarian dan nilai budaya masyarakat. Revitalisasi hanya dilakukan terhadap situs dan kawasan cagar budaya untuk memunculkan potensinya dengan memperhatikan tata ruang, tata letak, fungsi sosial, dan/atau lansekap budaya asli berdasarkan kajian.

Revitalisasi ini dilakukan dengan menata kembali fungsi ruang, nilai budaya, dan penguatan informasi tentang cagar budaya. Di samping itu revitalisasi juga harus memperhatikan ciri budaya lokal. Mengikuti prinsip pengembangan pada umumnya, revitalisasi harus memberi manfaat untuk meningkatkan kualitas hidup masyarakat. Sedangkan adaptasi merupakan upaya pengembangan terhadap bangunan, struktur, situs, dan kawasan cagar budaya untuk disesuaikan dengan kebutuhan masa kini dengan melakukan perubahan terbatas yang tidak akan mengakibatkan kemerosotan nilai pentingnya atau kerusakan pada bagian yang mempunyai nilai penting. Adaptasi dilakukan dengan mempertahankan nilai-nilai yang melekat pada cagar budaya, menambah fasilitas sesuai kebutuhan, mengubah susunan ruang secara terbatas dan/atau mempertahankan gaya arsitektur, konstruksi asli, dan keharmonisan estetka lingkungan di sekitarnya. Pengembangan lebih banyak berhubungan dengan potensi-potensi (intangible) yang menyatu dengan benda, bangunan, struktur, atau situs yang dipertahankan.

Kegiatannya bukan dalam bentuk konservasi, restorasi, atau pemeliharaan objek misalnya, melainkan upaya pengembangan informasi, penyusunan bahan edukasi, atau sebagai objek wista. Untuk itu perlu dilakukan pengelolaan pelestarian cagar budaya sesuai amanat pasal 95 ayat 1 UU nomor 11 tahun 2010 tentang cagar budaya "Pemerintah dan/atau PemerintahDaerah mempunyai tugas melakukan Pelindungan, Pengembangan, dan Pemanfaatan Cagar Budaya”.

Pemanfaatan merupakan pendayagunaan cagar budaya yang dilakukan dalam rangka meningkatkan kesejahteraan rakyat dengan tetap memperhatikan kelestariannya. Pemanfaatan cagar budaya dapat dilakukan untuk kepentingan agama, sosial, pendidikan, ilmu pengetahuan, teknologi, kebudayaan, 
danpariwisata. Untuk kepentingan ini pemerintah dan pemerintah daerah memfasilitasi pemanfaatan dalam bentuk pemberian izin pemanfaatan, dukungan Tenaga Ahli Pelestarian, dukungan dana, dan/atau pelatihan. Disamping itu diberikan juga fasilitas melalui promosi cagar budaya untuk memperkuat identitas budaya dan meningkatkan kualitas hidup dan pendapatan masyarakat.

Pemanfaatan yang dapat menyebabkan terjadinya kerusakan wajib didahului dengan kajian, penelitian, dan/atau analisis mengenai dampak lingkungan. Terhadap cagar budaya yang ke ka ditemukan sudah dak berfungsi dimungkinkan untuk dimanfaatkan untuk kepentingan tertentu. Ketentuan mengenai pemanfaatan sebenarnya cukup ketat termasuk kewajiban untuk meminta izin pemanfaatan, memperhatikan fungsi ruang, dan perlindungannya dan kewajiban untuk mengembalikan kondisi semula sebelum dimanfaatkan apabila cagar budaya tersebut dak lagi dimanfaatkan. Ketentuan lainnya terutama berkaitan dengan penggandaan benda-benda atau koleksi benda cagar budaya yang disimpan di museum.

Undang-Undang Nomor 11 Tahun 2010 tentang Cagar Budaya menegaskan bahwa Pemerintah atau Pemerintah Daerah mempunyai tugas melakukan Perlindungan, Pengembangan, dan Pemanfaatan Cagar Budaya. Namun pelaksaan perlindungan hukum terhadap benda cagar budaya yang di lakukan oleh Pemerintah daerah hingga saat ini di rasa lemah, karena masih terdapat beberapa benda cagar budaya yang rusak dan mengalami perubahan struktur fisik. Bentuk pengrusakan terhadap benda cagar budaya selama ini adalah dengan menambah bentuk aslinya.

\section{Kendala Yang Dihadapi Dalam Perlindungan Situs Cagar Budaya Taman Mayura}

Setiap kawasan cagar budaya memiliki corak tersendiri yang juga memiliki permasalahan khas karena keunikannya tersebut. Permasalahan kawasan cagar budaya dak hanya dipengaruhi oleh corak kawasannya, tetapi juga pengelolanya, khususnya komitmen pemerintah lokal yang memiliki tanggung jawab terhadap pelestarian dan kemampuan sumberdaya yang dimilikinya. Di bawah ini dikemukakan empat permasalahan utama dengan 
memberi fokus pada kasus-kasus kawasan cagar budaya yang dipilih untuk kajian ini. Keempat permasalahan tersebut berkaitan dengan status kawasan, perencanaan pengelolaanpenetapan zonasi dan konflik pemanfaatan.

a. Penetapan Status Kawasan Cagar Budaya Yang Belum Jelas.

Kutipan rumusan UU Cagar Budaya tahun 2010 di depan sudah jelas menyebutkan bahwa kawasan tersusun dari kumpulan lebih dari satu situs. Menurut prosedurnya, penetapan status suatu kawasan sebagai cagar budaya baru dapat dilakukan bila benda-benda, bangunan-bangunan, struktur-struktur, dan situs-situs yang ada di dalamnya telah ditetapkan lebih dahulu sebagai cagar budaya. Permasalahannya adalah bahwa sejumlah wilayah purbakala yang kini disebut dengan istlah kawasan cagar budaya, sebelumnya disebut istilah situs.

Permasalahan yang dihadapi sekarang adalah bagaimana status sejumlah kawasan cagar budaya yang sebelumnya ditetapkan sebagai situs? Penegasan ini penting mengingat konsep situs dan konsep kawasan yang diatur dalam UU cagar Budaya tahun 2010 memiliki arti berbeda, yang disebut pertama menjadi bagian dari yang kedua. Permasalahan kedua adalah semakin seringnya muncul situasi ketika sejumlah kawasan kepurbakalaan terancam rusak atau hancur oleh tindakan manusia, namun sulit dicegah karena kawasan tersebut belum ditetapkan sebagai cagar budaya. Persoalan utamanya adalah pada tataran mekanisme penetapannya. Terdapat penafsiran yang memang masuk akal bahwa penetapan kawasan harus didahului dengan penetapan situs-situs yang ada di dalamnya, sedangkan penetapan situs itu sendiri harus didahului oleh penetapan bangunan atau struktur yang mungkin ada di dalamnya. Selanjutnya jika di dalam bangunan terdapat bendabenda purbakala yang penting maka benda-benda itu juga harus ditetapkan statusnya sebagai cagar budaya.

Rangkaian prosedur penetapan status cagar budaya yang panjang itu tentu akan membutuhkan waktu lama. Tertunda-tundanya penetapan status tersebut berar_ memberi peluang semakin besar pada ak_ vitas destruk_f di kawasan kepurbakalaan yang tidak dapat dicegah. Dalam kenyataan, proses penetapan kawasan cagar budaya dengan mengiku_aturan 
UU yang baru belum pernah dilakukan sama sekali di Indonesia. Pertanyaannya, apakah penetapan status kawasan cagar budaya harus mengiku_prosedur lengkap sebagaimana digambarkan di atas. Jika memang harus demikian maka agenda pekerjaan pemerintah akan sangat banyak memakan waktu, tenaga, dan biaya.

b. Perencanaan Pengelolaan Kawasan yang tidak Tuntas

Pada umumnya, kawasan cagar budaya yang memiliki potensi tinggi untuk dimanfaatkan mendapatkan perhatian khusus. Hal ini tercermin dari upaya-upaya pengelolaan kawasan yang disiapkan secara serius dengan membuat dokumendokumenperencanaan yang dikenal sebagai naskah rencana induk atau masterplan. Namun sayangnya masterplan-masterplan itu _ dak dapat dilaksanakan sesuai rencana, bahkan ada pula yang tidak dapat dituntaskan. Menurut prosedur, masterplan hanya dapat dibuat ke_ ka status kawasan yang bersangkutan sudah ditetapkan sebagai cagar budaya. Kawasan Sangiran misalnya telah ditetapkan sebagai (benda) cagar budaya pada tahun 1977 melalui SK Mendikbud, kemudian ditetapkan sebagai situs warisan dunia oleh UNESCO pada 7 Desember 1996. Namun masterplan untuk pengelolaan kawasannya baru disusun pada tahun 2006. Masterplan tersebut dirancang untuk rencana lima tahun sampai dengan 2011 (Ditjen Sejarah dan Purbakala 2006).Namun demikian, hingga tahun ini (Oktober 2013) pelaksanaan program-programyang direncanakan belum dapat dituntaskan.

c. Penetapan zonasi yang kurang melindungi keseluruhan aset kawasan.

Zonasi merupakan kegiatan yang sangat penting dalam rangka perlindungan kawasan cagar budaya, namun dalam praktek tidak jarang menghadapi banyak kendala, bahkan sering masalah dibiarkan tidak dituntaskan.

\section{d. Konflik Pemanfaatan dan Pengelolaan}

Ada dua sumber konflik utama yang berkaitan dengan pemanfaatan kawasan cagar budaya, yaitu masalah lahan dan masalah cagar budayanya sendiri. Terdapat korelasi antara tingkat konfl ik dengan kondisi kepemilikan 
lahan. Di kawasan-kawasan cagar budaya yang status kepemilikan tanahnya lebih banyak dikuasasi oleh masyarakat, maka tingkat potensi konfl iknya relative tinggi. Hal ini berkaitan dengan lemahnya dukungan hukum bagi pengelola untuk melindungi temuan-temuan arkeologi yang ada di atas dan di dalam tanah milik masyarakat. Termasuk di dalamnya adalah sulitnya mengendalikan pemanfaatan lahan untuk keperluan pertanian, perumahan danpembangunan sarana publik, baik yang dilakukan atas dasar hak kepemilikan pribadi, penyewaan lahan maupun penjualan lahan. Kasus sepert ini terjadi dimana-mana, tidak terkecuali di Borobudur, Banten Lama, dan Kota Tua Jakarta. Permasalahan konflik akan semakin kompleks bila kawasan cagar budaya yang dimanfaatkan merupakan wilayah pemukiman padat yang sedang berkembang seperti halnya di Trowulan, Banten Lama dan terlebih lagi di Kawasan Kota Tua Jakarta (Sulistiyanto 2008; Hamid, 2009; Rahardjo 2011). Sumber konflik lain adalah status kepemilikan atau penguasaan cagar budayanya sendiri.

Upaya perlindungan hukum cagar budaya dapat dilakukan dengan menerapkan pasal 95 UU No 11 Tahun 2010 tentang Cagar Budaya. Selain itu upaya perlindungan cagar budaya dari kerusakan adalah dengan memasang papan petunjuk,larangan, ajakan, dan keterangan, pembentukan petugas keamanan, pelaporan tindak pidana, penyelidikan terhadap kasuskasus tindak pidana. Maka dari itu diperlukan penjagaan atas arca, baik dari aspek fisik maupun legalitasnya.

Untuk menjaga kelestarian cagar budaya maka diperlukan langkah pengaturan bagi penguasaan, pemilikan, penemuan, pencarian, perlindungan, pemeliharaan, pengelolaan, pemanfaatan, dan pengawasan. Karena selama ini masih banyak masyarakat yang belum memahami sanksi hukum yang diberikan terkait dengan perusakan cagar budaya. Hanya saja masih terdapat hambatanhambatan yang dihadapi oleh pemerintah daerah dan pengelola taman mayura.

\section{Kendala Pemerinatah Daerah}

Faktor kendala yang dihadapi oleh Pemerintah Daerah Kota mataram dalam memberikan perlindungan hukum terhadap Cagar Budaya Pura taman mayura yaitu sebagai berikut 
a. Faktor Internal:

(1) kurangnya anggaran dibidang kebudayaan yang mengakibatkan program pelestarian cagar budaya yang telah disusun tidak sepenuhnya bisa terlaksana.

(2) Pemerintah Daerah dalam hal ini eksekutif dan legislatif belum menganggap pelestarian cagar budaya merupakan urusan daerah yang urgen sehingga pelestarian cagar budaya belum dilaksanakan dengan serius.

(3) Belum ada peraturan daerah yang mengatur secara khusus mengenai cagar budaya.

b. Faktor Eksternal:

b. Kesadaran masyarakat akan hak dan kewajiban dalam pelestarian cagar budaya masih lemah.

c. Belum adanya sosialisasi secara luas bahwa taman mayura sebagai cagar budaya yang harus dilindungi dan dijaga keberadaaanya.

d. Adanya masyarakat yang belum memiliki kesadaran dan pengetahuan akan pentingnya nilai-nilai kebudayaan, dan benda cagar budaya.

Upaya yang dilakukan pemerintah daerah untuk mengatasi kendala tersebut

a. Upaya yang telah dilaksanakan:

(1) Melakukan penyuluhan tentang pentingnya pelestarian cagar budaya untuk mewujudkan, menumbuhkan, dan mengembangkan kesadaran masyarakat akan pentingnya cagar budaya bagi bangsa.

(2) Memperkuat koordinasi dan kerjasama dengan masyarkat untuk meningkatkan pengawasan terhadap cagar budaya taman mayura

(3) Membuat rencana dan anggaran dalam rangka pengembangan cagar budaya.

(4) Meningkatkan anggaran untuk pelestarian cagar budaya di daerah.

\section{Kendala Pengelolaan Taman Mayura}

Didalam pengelolaan taman mayura sebagai cagar budaya ada permasalahan yang dihadapi oleh pengelola yakni sebagaia berikut ; 
(1) Pura taman mayura dalam pengelolaanya menjadi tanggung jawab yayasan krama pura meru, kenapa diatasnamakan yayasan krama pura meru agar tidak terjadi sengketa dikemudian hari dengan ahli waris yang mewarisi taman mayura tersebut, adapun lahan ditaman mayura sudah bersertifikat atas nama krama pura. Karena pengelolaan oleh yayasan sering terjadi kesalahpahaman antara tanggungjawab pemerintah dan yayasan sejauh mana dalam batas batas cagar budaya.

(2) Tidak adanya anggaran operasional dari pemerintah daerah untuk melakukan perawatan situs cagar budaya taman mayura.

(3) Kurangnya pemahaman masyarakat tentang artic agar budaya sehingga kendala yang duhadapi masalah kebersihan sampah, banyak pengunjung yang membuang sampah sembarangan walaupun sudah disediakan keranjang sampah. Selain itu ketika pohon mangga dan buah manggis berbuah banyak pengunjung yang memetic sembarangan tanpa seijin pengurus pura.

(4) Kurangnya petugas kebersihan dari dinas pariwisata hanya berjumlah 4 orang belum memenuhi standar dibandingkan areal yang harus dibersihkan.

(5) Belum jelasnya batas zonasi cagar budaya pura taman mayura sehingga menyebabkan terjadinya konflik sengketa kepemilikan lahan yakni lahan yang menjdi lapangan tenis saat ini status kepemilikannya apakah milik pemda atau yayasasn

\section{E. Kesimpulan}

Berdasarkan uraian pada bab diatas dapat ditarik kesimpulan Perlindungan hukum terhadap cagar budaya taman mayura dilakukan atas dasar aturan yang dalam peraturan perundang undangan. kendala kendala yang dihadapi dalam pengeloaan cagar budaya pura taman mayura terdapat dua kendala yakni dari pemerintah daerah seperti belum adanya peraturan daerah yang mengatur tentang cagar budaya dan yang kedua dari pengelolaan sendiri yang sering tumpeng tindih antara yayasan dan pemerintah terkait dengan tanggungjawab apabila terjadi kerusakan cagar budya. 


\section{Daftar Pustaka}

\section{Buku}

Ata, Andre Ujan. 2009. “Membangun Hukum Membela Keadilan”. Yogyakarta. Adi, Rianto. 2005. “Metodelogi Penelitiaan Sosial Dan Hukum”. Jakarta : Granit. Achmad Dan Heryani Wiwie .2012. “Asas Asas Hukum Pembuktian Perdata”. Jakarta : Kencana Prenada Media Group

Arikunto,Suharsimi. 2006. "Prosedur Penelitian Suatu Pendekatan Praktik”.Jakarta. PT. Rineka Cipta.

Ali, Zainudin. 2009. “Metode Penelitiaan Hukum”. Palu. Sinar Grafika.

Arrasjid,Chainur.2000. “Dasar-Dasar Ilmu Hukum”. Medan. Sinar Grafika.

Faisal, Sanapiah, 1990. Penelitian Kualitatif (Dasar Dasar Dan Aplikasi) Malang : Ya3 Malang

Fajar. Mukti dan Achmad, yulianto. 2017. Dualisme Penelitian Hukum Normatif \& Empiris. Yogyakarta : pustaka pelajar.

Fuandy, Munair. 2013. Teori-Teori Besar (Grand Theory) Dalam Hukum.

Hadjon, M Philipus. 1987. Perlindungan Hukum Bagi Rakyat Indonesia.

Surabaya: Bina Ilmu.Jakarta. Kencana.

Dewa A Nyoman Kusumaningrat, 2004 Buku Pelajaran Agama Hindu Untuk Kelas $6 S D$ (Semester 1\&2), Surabaya: Paramita.

Mertokusumo, Sudikna. 1993. “Bab-Bab Tentang Penemuaan Hukum”. Yogja : PT Citra Aditya Bakti.

Moleong, 2002. Metodologi Penelitian Kualitatif. Bandung :PT Remaja Rosdakarya.

Nasution. 2008. “Metode Research”. Jakarta. PT. Bumi Aksara Raharjo, Satjipto. 2006. “Ilmu Hukum. Bandung”: PT Citra Aditya Bakti.

Soekanto, Soerjono. 1983. “Faktor-Faktor Yang Mempengaruhi Penegakan Hukum”. Jakarta. Pt. Raja Grapindo Persada.

Soekanto, Soerjono. 2012. "Sosiologi suatu pengantar”. Jakarta. Rajawalai press. Sugiyono. 2014. "Metode Penelitiaan Pendidikan Pendekatam Kualitatif ,KuantitatifDan R\&D”. Bandung : Alfabeta

Sunggono, Bambang. 2010. “Metode Penelitiaan Hukum”. Jakarta. PT. Raja 
Grapindo Persada.

Nasir, Muhamad Abdun, 2015" Perlindungan Hukum Terhadap Cagar Budaya di Kabupaten Semarang (Studi Tentang Perlindungan Hukum Situs Cagar Budaya Candi, Universitas Semarang).

Tim Penyusun. 2001. Peninggalan Sejarah Dan Kepurbakalan NTB. Departemen pendidikan nasional kanwil NTB. Mataram

\section{Peraturan dan Perundang-Undangan :}

Undang-Undang Dasar Negara Republik Indonesia Tahun 1945

Undang Undang Nomor 11 Tahun 2010 Tentang Cagar Budaya

\section{Sumber Internet}

https://hindualukta.blogspot.com/2015/12/pengertian-dan-fungsi-tempat-sucipura.html

https://cagarbudaya.kemdikbud.go.id/public/objek/detailcb/PO2016060600002/taman$\underline{\text { mayura }}$

http://lombokoption.co.id/pura-taman-mayura/ 